\title{
The Place of Fault in Grotius's Conception of Liability for Wrongdoing
}

\author{
Joe Sampson \\ University of Oxford, United Kingdom \\ joe.sampson@magd.ox.ac.uk
}

\begin{abstract}
This article compares Grotius's treatments of liability for wrongdoing in natural law and the law of Holland to emphasise the conceptual centrality of fault in both, and places Grotius's analyses in their historical context by tracing the treatment of strict liability in those intellectual traditions upon which he drew. It focuses in particular on the formulation of obligations quasi ex maleficio to show how the absence of fault rendered the obligation something other than delictual.
\end{abstract}

\section{Keywords}

delict - fault - strict liability - quasi-delict

\section{$1 \quad$ Introduction}

To understand the place of fault in Grotius's delictual doctrine, we ought to begin with his intellectual foundations. Since the topic was first explored in detail by Feenstra, it has been recognised that Grotius drew upon two pools of resources in formulating his account of liability for wrongdoing: orthodox civilian learning and the juridified theology of sixteenth- and seventeenth-century Thomists. ${ }^{1}$ In both of these sources of intellectual influence, it will be seen

1 Robert Feenstra, 'Grotius' Doctrine of Liability for Negligence: Its Origin and its Influence in Civil Law Countries until Modern Codifications', in: Negligence: The Comparative Legal History of the Law of Torts, ed. by Eltjo Schrage (Berlin: Duncker \& Humblot, 20o1); Robert Feenstra, 'Linfluence de la scolastique espagnole sur Grotius en droit privé', in: La seconda scolastica 
that fault was inescapable. Although both traditions offered avenues for the dilution of fault to the point of near strict liability and experienced no small degree of cross-pollination, ${ }^{2}$ the language and trappings of fault were omnipresent. With this in mind, the central place of fault in Grotius's natural law is far from surprising. We will turn then to his account of the law of Holland. Here, Grotius was forced to engage with longstanding heads of strict liability in local law. Rather than accepting these for what they were beneath the aegis of delict, Grotius offers an inconsistent approach to circumventing the underlying strict nature of such obligations. Sometimes they are explained in manners that allude to a fault; sometimes they are instead pushed into the category of obligations quasi ex maleficio, with Grotius denying that they can truly be species of maleficium for want of fault. On either footing, the centrality of fault to wrongdoing is plain.

Strict liability would find three potential foundations in the texts of the ancient jurists: through explorations of custodia in contract, culpa levissima in the lex Aquilia, and the existence of obligations quasi ex delicto. None of these appears to have been viewed as analogous to modern strict liability by the classical jurists but instead represent pockets of doctrine where the orthodox approaches to fault in contract and delict are displaced. Though anomalous to differing degrees within their ancient contexts, these would provide bases for discussions of the lower limits of fault in medieval commentaries on the Corpus and beyond. It is beyond the ambitions of this section to offer a detailed account of these species of liability. Instead, it seeks to show the awkward juxtaposition of these areas when viewed in situ and provide an outline of their subsequent development to understand better the role strict liability had within the law of obligations at the time of Grotius.

\subsection{Contract, culpa and custodia}

The Roman law of contracts has an intricate hierarchy of fault standards based around dolus, culpa, and casus, with the language of culpa subdivided into

nella formazione del diritto privato moderno, ed. by Paolo Grossi (Milan: Giuffré, 1973), pp. 377-402; Nils Jansen, Theologie, Philosophie und Jurisprudenz in der spätscholastischen Lehre von der Restitution (Tübingen: Mohr Siebeck, 2013), pp. 176-87; Joe Sampson, The Historical Foundations of Grotius' Analysis of Delict (Leiden: Brill, 2018).

2 Sampson, The Historical Foundations of Grotius' Analysis of Delict, pp. 209-25. 
lata and levis, and levis subject to further division according to differing views on whether it was best established through analyses of the defendant's own standards of conduct (in concreto) or those of the archetypical bonus paterfamilias (in abstracto). ${ }^{3}$ These standards were not presented as a hierarchy per se in the ancient texts. Still, the array of conceptual labels deployed across the contractual texts shows a clear sensitivity to the different ways in which questions of fault can be approached and a contextual understanding of when different methods might be appropriate. Alongside this structure existed a separate concept of custodia, which typically surfaces in contracts involving work on another's property, as in the case of a fuller repairing clothes, with an attached duty of safekeeping. The nature of this liability is a topic of significant controversy. For some, it represents a specific duty to safeguard the property; for others, it is a species of objective (strict) fault to be juxtaposed with the subjective analyses of dolus and culpa: simply allowing harm to befall the entrusted property sufficed for liability. ${ }^{4}$ It has been argued that this debate is straightforwardly anachronistic, imposing on the Roman texts the nineteenthand twentieth-century debates that accompanied the emergence of new technologies and the liability regimes that ought to govern them. ${ }^{5}$ This rings true insofar as the compilers did not appear to be troubled by the potential conflict between custodia on the one hand, and dolus and culpa on the other, with individual contractual arrangements giving rise to liability through both prisms. But it is equally true that custodia represents a different approach to the determination of liability in a contractual setting. Later generations well before the nineteenth century would perceive and reflect on the nature of this difference, as well as its implications for the necessity of fault.

\section{$2.2 \quad$ Delict, culpa levissima, and obligations quasi ex delicto}

The Roman patchwork of delicts did not begin with a systematic approach to fault concepts, but well before classical law, the trichotomy of dolus, culpa, and casus characterised the treatment of fault standards across the law of obligations. ${ }^{6}$ Intentionality was at the heart of delict. This idea found expression in

3 David Ibbetson, 'The Law of Business Rome: Foundations of the Anglo-American Tort of Negligence', Current Legal Problems 52 (1999), 74-109 (pp. 81-83).

4 E.g. Carlo Cannata, Ricerche sulla responsabilità contrattuale I (Milan: Giuffrè, 1966); Antonino Metro, La obbligazione di custodire (Milan: Giuffrè, 1966); Claude Alzon, Problèmes relatifs a là location des entrepôts en droit romain (Paris: Editions Cujas, 1966).

5 E.g. G. Van den Bergh, 'Custodiam Praestare: Custodia-Liability or Liability for Failing Custodia?', Tijdschrift voor Rechtsgeschiedenis 43 (1975), 59-72 (pp. 59-6o).

6 David Daube, Roman Law: Linguistic, Social and Philosophical Aspects (Edinburgh: Edinburgh University Press, 1966), pp. 131-156. 
numerous forms, from the general dolus to the more specific animus furandi, describing that species of intention that characterises furtum. ${ }^{7}$ Of the institutional delicts, only damnum iniuria entertained a lesser fault standard: culpa $^{8}$ By contrast with the stratification of culpa into distinct degrees of fault in contract law, the culpa of damnum iniuria was unitary and largely undefined. Efforts to lay down an abstract understanding of this species of culpa appear to have been rare in antiquity, with the Digest primarily using Ulpianic texts that present a range of culpable factors and sometimes go as far as to leave conclusions to the reader. ${ }^{9}$ In essence, the delictual culpa involved asking who was to blame for the harm. Though Paul did seek to offer a more philosophical approach in conceptualising culpa as failing to the care of a diligens paterfamilias, ${ }^{10}$ it is noteworthy that the compilers of the Digest included few similar abstractions, and Justinian's Institutes redefined Paul's scenario in the casuistic terms of Ulpian's fault analyses."1

Beneath an overarching, almost self-understood notion of fault, specific concretisations such as want of skill (imperitia) found expression, hinting at contextualised expectations and standards of behaviour. Among these is a cryptic statement by Ulpian that 'In the lex Aquilia even the slightest fault [culpa levissima] counts.' ${ }^{12}$ The idea of culpa levissima would receive no elaboration and does not feature elsewhere in the Digest. It is thought today that the text had but a narrow scope in classical Roman law, not least due to the absence of any other reference to the concept it describes. ${ }^{13}$ By contrast, earlier generations of Romanists thought the text far more general, and from the glossators onwards, culpa levissima would be the vehicle for exploring the lower limits of culpa needed before liability could be imposed. So far as the sources for classical law are concerned, however, Dig.9.2.44.pr is an outlier.

The institutional delicts all had robust fault standards, and the myriad supplementary wrongs described in book 47 of the Digest are similarly committed

7 E.g. Dig. 47.2.25.2. Later generations would introduce a parallel in iniuria, the animus iniurandi, but this was not authentically Roman.

8 Gai. Inst. 3.211.

9 E.g. Dig. 9.2.11.pr, Dig. 9.2.9.4, Dig. 9.2.57, Dig. 9.2.29.2, Dig. 9.2.52.1 - all of which involve analyses predicated on 'if this person is to blame...', rather than a clear path to determining who is to blame.

$10 \quad$ Dig. 9.2.31.

$11 \quad$ Inst. 4.3.4.

12 Dig. 9.2.44.pr (Ulpian): 'In lege Aquilia et levissima culpa venit.'

13 Geoffrey MacCormack, 'Aquilian culpa', in: Daube Noster: Essays in Legal History for David Daube, ed. by Alan Watson (Edinburg: Scottish Academic Press, 1974), p. 204; Olga TellegenCouperus, 'The Limits of culpa levissima', Tijdschrift voor Rechtsgeschiedenis 76 (2008), 19-25. 
to the need for fault. The centrality of fault to delict is alluded to, but not definitively proven, by the underlying conceptualisation of the category of obligations quasi ex delicto. Attempts to explain the underlying theorisation of this category have long focused on identifying some shared characteristic which explains why the obligations cannot truly be delictual. Though no single explanation has proved popular to the exclusion of others, the recurring idea is that the obligations quasi ex delicto did not require proof of fault. ${ }^{14}$ Though ius commune scholars did not go this far, they too perceived that differing approaches to fault (such as true delicts requiring dolus and quasi-delicts requiring only culpa) could explain the taxonomical distinction. ${ }^{15}$

\subsection{Culpa levissima in the ius commune}

During the second life of Roman law, the two possible foundations for strict liability - culpa levissima in the context of the lex Aquilia and the contractual custodia - were brought together. Indeed, the language of fault across the two contexts was largely unified. As in antiquity, fault was placed at the heart of delict. Where the ancient approach to culpa in delict had been largely unitary, medieval jurists introduced instantiated degrees of responsibility clearly inspired by the Roman contracts. ${ }^{16}$ Drawing upon the language such as levis and levissima used in the classical texts, a six-tiered ladder of fault standards was developed, with the missing comparative degrees of latior and levior supplied by the likes of Bartolus. ${ }^{17}$ Each degree of fault was given an abstract definition, inspired by Paul's example in Dig.9.2.31 and various contractual texts.

Within this structure, culpa levissima formed the lowest rung of fault. Rossi has shown at length the plurality of approaches that the commentators adopted in approaching culpa levissima, with an agreed definition proving evasive. ${ }^{18}$ The expectations of the most diligent men acting within their profession came to dominate, with the same standards of those men in everyday

14 Eric Descheemaeker, The Division of Wrongs: A Historical Comparative Study (Oxford: Oxford University Press, 20o9), chapters 3 and 4.

15 Ibid., pp. 73-6.

16 Jan Hallebeek, 'Negligence in Medieval Roman Law', in: Negligence: The Comparative Legal History of the Law of Torts, ed. by Eltjo Schrage (Berlin: Duncker \& Humblot, 2001).

17 On the curious invention of culpa levior, Hans-Joachim Hoffmann, Die Abstufung der Fahrlässigkeit in der Rechtsgeschichte, unter besonderer Berücksichtigung der culpa levissima (Berlin: De Gruyter, 1968), pp. 51-2.

18 Guido Rossi, 'The Liability of the Shipmaster in Early Modern Law: Comparative (and Practice-Oriented) Remarks', Historia et Ius 12 (2017), 1-47 (pp.6-16). 
affairs constituting culpa levis. ${ }^{19}$ This provided a platform for a species of professional liability, particularly in relation to maritime trade. In practical terms, this approach to culpa levissima might be no different to strict liability. Our fictitious paragons of diligence can foresee all that is humanly possible, and so the standard of culpa levissima serves to exculpate only those who fell victim to unforeseeable chance. Anyone who falls short of this ideal will be liable, regardless of the precautions they took to offset the harm. The distance between such a standard of care and strict liability as we know it today is razor-thin. It is nevertheless significant that the potential for strict liability was couched in the language of culpa: liability could not be imposed without some de minimis hint of fault on the part of the wrongdoer. This is no true strict liability.

\section{Thomism}

Fault would play no less central a role in the juridified theology of the Thomists, who built a sophisticated legal edifice atop the writings of Thomas Aquinas. At the heart of Aquinas's private law is the idea of corrective justice, the equilibrium of assets (material and otherwise) between individuals maintained through the requirement to make restitutio whenever it was unjustifiably disturbed. ${ }^{20}$ In his treatment of justice in the Summa theologiae, Aquinas details a number of sins that, if committed, trigger the need for restitutio. These range from the remarkably general iniustitia (a term used to refer both to the general character of acts contrary to justice and the particular sin of causing someone to have less than they are due) to the specific manifestations of judicial and extrajudicial verbal wrongs, traversing murder, mutilation, theft, usury, and various others in the process. ${ }^{21}$

In his detailed discussion of each sin, it is noticeable how little space is dedicated to questions of fault. Indeed, for the section on accidental killings in the quaestio on homicide, the topic is conspicuously absent. ${ }^{22}$ This is because it is pushed into a general treatment of the preconditions of sinfulness, itself couched in the language of voluntariness. This builds directly on Aristotle's belief that praise and blame are attracted only by actions that are hekousion,

19 Rossi, 'The Liability of the Shipmaster in Early Modern Law', p. 11, especially n.44.

20 Sampson, The Historical Foundations of Grotius' Analysis of Delict, pp. 129-63 provides an overview of the framework for corrective justice in Aquinas's Summa Theologiae.

21 Aquinas, ST, II-II, qq.62-78.

22 Aquinas, ST, II-II, q.64.a.8. 
which for Aquinas becomes voluntarius. ${ }^{23}$ No action that causes harm can be labelled sinful, resulting in an obligation to repair the harm caused, unless it is voluntary.

The account of voluntariness offered by Aquinas is complex and not wellsuited to the realities of legal practice. An act is voluntary when it is performed with knowledge of the injustice that will flow from its performance. ${ }^{24}$ What, then, is knowledge? In addition to 'actual' knowledge, there are three further species of 'constructive' knowledge: concomitant, consequential, and antecedent knowledge. ${ }^{25}$ Concomitant ignorance catches those who are ignorant of the injustice their actions will cause but would have acted in the same way if aware of the outcome; consequential ignorance applies to cases of wilful blindness and (in modern terms) negligence, where the wrongdoer knowingly closes their mind to the risk they pose, or else ought to have been aware of that risk; and antecedent ignorance is the absence of knowledge which would have affected the actions of the wrongdoer, but which is beyond the realms of what the actor is expected to know. Of these three species, consequential knowledge is always sufficient for voluntariness, antecedent knowledge always renders an action involuntary, and concomitant ignorance lies somewhere in the middle. ${ }^{26}$

This classification of the species of knowledge is theologically neat but legally unworkable. As such, later generations writing commentaries on Aquinas would turn to legal treatises when tackling questions of fault. The Thomists of later centuries differed in the degree to which they relied on earlier theological sources, or sought to integrate them with contemporary juristic learning. The Summa angelica defines culpa in legal terms even when linking it to Aquinas's restitutio, a definition that is supplemented with references to Bartolus instead of theology. ${ }^{27}$ Cajetan reformulated Aquinas's discussion of fault in the case of accidental homicide in terms of diligentia and negligentia, reframing the issue in terms lifted from Gratian. ${ }^{28}$ In authors such as these, there is a clear attempt to superimpose the legal language of fault onto the

23 Aristotle, eth. Nic. 3.1; ST, I-II, q.18.a.6: 'neque actus exteriores habent rationem moralitatis, nisi inquantum sunt voluntarii'.

24 Aquinas, ST, I-II, q.6.a.1.

25 Aquinas, ST, I-II, q.6.a.8.

26 For a fuller account of Aquinas on voluntariness, see Sampson, The Historical Foundations of Grotius's Analysis of Delict, p. $156 \mathrm{ff}$.

27 Di Chivaso, Summa Angelica, 97 ('de verbo culpa').

28 James Gordley, Foundations of Private Law: Property, Tort, Contract, Unjust Enrichment (Oxford: Oxford University Press, 2007), p. 201 n.122, citing C.2.q.5.c.2. 
theological source material. However, the result was an explosive plurality of views on the best way to achieve this end.

Two theological authors upon whom Grotius relied offered almost entirely juridified accounts of fault. The first is Navarrus. In his Enchiridion, a commentary on the Ten Commandments, we find the familiar Roman trichotomy of dolus, culpa, and casus, with subdivisions into lata, levis, and levissima. This is not as intricate as the medieval commentators' six-fold classification of fault, but its foundations in civilian learning are obvious. In approaching each of these terms, Navarrus attempts to show common foundations in both Aquinas and civilian sources. The Thomist fraus and fallacia are just the civilian dolus verus and dolus praesumptus by different names: though the labels used by the two traditions differ, the underlying conceptual frameworks are compatible, if not the same. ${ }^{29}$ It is similarly noteworthy that when offering definitions of the various species of culpa, references to Aquinas are few in number. ${ }^{30}$ While ostensibly a reconciliation of Thomism and law, Navarrus appears to be offering something closer to a displacement of the former by the latter.

Navarrus's work was taken a step further by Lessius, the Thomist who most influenced the delictual thought of Grotius. ${ }^{31}$ Shedding the language of dolus for an analysis couched entirely in terms of culpa, he offers a fivefold structure strongly reminiscent of civilian treatises:

Culpa latissimus is the same as dolus apertus; latior is the same as dolus praesumptus. This is any callidity, deception or machination designed to deceive. Callidity is keeping silent, deception is lying, and machination is done by words... Culpa lata is a failure of diligence in the circumstances, that standard which the same sort of men are used to living by; for instance, leaving a loaned book outside the house. Culpa levis is a failure of diligence in the circumstances, that standard which more careful men adhere to in their professional practice. Culpa levissima is a failure of diligence, the standard or the most careful and prudent men. ${ }^{32}$

29 Navarrus, 17.177-181.

$30 \quad$ Navarrus, 17.178 .

31 Sampson, The Historical Foundations of Grotius' Analysis of Delict, pp. 229-44.

32 Lessius, 2.7.6: 'Culpa latissimus est dolus apertus: latior, est dolus praesumptus. Est autem dolus quaevis calliditas, fallacia et machinatio ad circumveniendum, fallendum, et decipiendum adhibita. Calliditas fit tacendo, fallacia mentiendo, machinatio arte verborum... Culpa lata est omissio eius diligentiae et circumspectionis, quam passim homines eiusdem conditionis adhibere solent: ut si quis librum commodatum relinquat foris ante ostium. Culpa levis est omissio eius diligentiae et circumspectionis, quam solent diligentiores illius artis vel professionis adhibere. Culpa levissima est omissio diligentiae, quam diligentissimi et prudentissimi adhibent.' 
The Roman roots of Lessius's account are clear, from the definition of dolus ${ }^{33}$ as well as its division into apertus and praesumptus ${ }^{34}$ to the substantiation of the degrees of culpa levis and levissima. The only missing element from an orthodox Bartolus-inspired approach to fault is the sixth degree, culpa levior. As Rossi notes, this was the one fault standard that was not authentically Roman, with its antonym culpa latior being spuriously linked to Dig.16.3.32. So its omission is not terribly surprising. ${ }^{35}$

By the early seventeenth century, Grotius's intellectual forbearers were arriving at a common solution to the treatment of fault. The same language was used to formulate analyses of contract and delict in the civilian world, and infiltrated the theological commentaries on private law of the Thomists. Within this setting, culpa levissima represented the lowest degree of fault permissible before an event was to be branded an accident and consequently escape liability. In practical terms, culpa levissima might be seen as akin to strict liability. There are always precautions that the omnicapable vir prudentissimus might have taken that everyday tortfeasors would overlook. But even these scenarios were cast in the language of fault. It was straightforwardly an inescapable precondition of delictual liability that the defendant is found to have exhibited something that can be described as culpable.

\section{Grotius's Natural Law}

In light of Grotius's influences, the approach taken in his natural law writings was essentially pre-determined. To remove fault from the DNA of liability for wrongdoing would not be a doctrinal tweak but a fundamental change in the scope and nature of such liability. Grotius was not innovative in his delictual thinking, drawing instead heavily on a handful of Thomist authors. So it is not surprising to see a similarly central role for fault to play in De jure belli ac pacis's treatment of the subject. Fault is identified with the very heart of wrongdoing in the opening passage of the relevant chapter:

Maleficium hic appellamus culpam omnem, sive in faciendo, sive in non faciendo, pugnantem cum eo quod aut homines communiter, aut pro ratione

33 Strongly reminiscent of Labeo's definition of dolus in Dig.4.3.1.2.

34 Linked to Baldus: On dolus praesumptus in Baldus, see Alexander Löffler, Die Schuldformen des Strafrechts: In vergleichend-historischer und dogmatische Darstellung (Leipzig: Hirschfeld, 1895), p. 156; on dolus apertus in Baldus, see Franco Cordero, Criminalia: nascita dei sistemi penali (Rome: Biblioteca universale Laterza, 1986), p. 268.

Rossi, 'The Liability of the Shipmaster in Early Modern Law', p. 7, n.2O. 
certae qualitatis facere debent. Ex tali culpa obligatio naturaliter oritur, si damnum datum est, nempe ut id resarciatur. ${ }^{36}$

The opening sentence clearly links the species of liability, maleficium, to culpam omnem. The title of the chapter draws the same link: 'culpam obligare ad restitutionem damni'. The idea is substantiated through a series of notions. The inclusion of sive in faciendo sive in non faciendo, in commission or omission, is Grotius's mean of alluding to the complex matrix of means by which a person might contribute to a wrong, lifted from Thomist theology and elaborated upon at length later in the chapter. ${ }^{37}$ The notion of expected behaviours captured by pugnantem cum eo quod aut homines communiter, aut pro ratione certae qualitaties facere debent collapses into one clause the ideas of culpa levis and levissima as articulated in contemporary treatises. What one ought to do by 'common standards' represents the behaviour of the ordinary person, culpa levis, whereas particular expectations stemming from a person's position allude to culpa levissima.

The content of fault receives little elaboration beyond this sentence. It appears unthinkable that liability could be imposed in the absence of fault, but Grotius does not approach the concept through the dogged demarcations seen in earlier civilian texts, though as just seen, he does wink at their content. Instead, his idea of fault is more elastic. This can be seen in the context of compelled behaviour:

At qui causam dedit cur vim pati, aut metu cogi debeat habet quod sibi imputet. Nam involuntarium exvoluntario ortum habens moraliter pro voluntario habetur. ${ }^{38}$

Here coerced conduct is treated as voluntarily performed where it flows from a voluntary choice. This is reminiscent of discussions of prior fault that Aquinas once labelled 'concomitant ignorance', an idea more at home in texts of moral philosophy than the more instantiated analyses of juristic writers. Passages like this give the impression that for Grotius, fault was a concept with fluid parameters, especially when compared to the rigid structures seen earlier

36 Grotius, $I B P$, 2.17.1.

37 Grotius, $I B P, 2.17 .6$. For a fuller analysis of the variety of causal contributions that could result in liability, see Sampson, The Historical Foundations of Grotius's Analysis of Delict, pp. 230-3; Sampson, 'The Limits of Natural Law: Liability for Wrongdoing in the Inleidinge', Grotiana 40 (2019), 7-27 (pp. 17-20).

38 Ibid., 2.17.18: 'When a person has himself been the occasion of the fraud or violence, the consequences are imputable to his own conduct. For where a voluntary act gives rise to 
in this article. But this should not be seen as diminishing its importance. It remained the case that liability for wrongdoing was a species of obligation arising 'ex tali culpa' ${ }^{39}$

There is only one hint that fault might not always be necessary. ${ }^{40}$ It groups together three analytically similar though doctrinally distinct scenarios: noxal liability, liability for animals, and liability for ships. Such heads of liability are expressly said not to arise from natural law sources, precisely because the defendant is not at fault for the harm caused by his slave, animal, or ship. ${ }^{41}$ Rather, these sources of obligation are being discussed due to their universality in positive legal systems. Their inclusion is clearly anomalous, and so Grotius makes a rather thin effort to show their relevance to obligations arising out of wrongdoing. Despite having just said that these could not be natural obligations due to the absence of fault, he goes on to claim that the way in which local legal systems deal with such wrongs - such as through the equal division of damages between the parties - is due to the difficulty of proving fault. This presumption of fault provides a way of reconciling these otherwise anomalous species of liability with the natural law framework. This means of reconciliation presumably only relates to harm caused by ships, as it is only such wrongs that carry the unique remedy Grotius describes. Still, the manner in which he presents the material suggests he believes the same rationale of presumed fault applies to noxal liability and liability for animals as well.

The concept of fault plays a central role in Grotius's natural law account of liability for wrongdoing. Indeed, the category of obligations could be described without distortion as arising from fault. Despite this centrality, Grotius is conceptually difficult to pin down. His core definition of this species of liability in 2.17.1 can be traced back to the juridified theology of the Thomists in its reference to differing causal contributions, and to both those authors and civilian orthodoxy in its use of duty to substantiate when a person can be said to be at fault. But beyond these observations, there is little more to be said about the lynchpin concept of culpa. Indeed, his willingness to slip between the language of negligens and culpa suggests a degree of imprecision in Grotius's own use of the term. This is not to be seen as a tightly juridical concept, but a self-understood term of societal condemnation. It is, nevertheless, indispensable for liability for wrongdoing.

involuntary consequences, those consequences, considered in a moral light, are to be deemed the fruits growing out of the exercise of a free will.'

39 Grotius, $I B P$, 2.17.1.

40 Grotius, $I B P, 2.17 .21$.

41 Grotius, IBP, 2.17.21: 'nam dominus, qui in culpa non est, natura ad nihil tenetur.' 
The problem of ship collisions is revealed in full when turning to Grotius's writings on the law of Holland. His Inleidinge tot de Hollandsche rechtsgeleerdheid is an institutional text presenting much the same content as his natural law treatise interwoven with the contemporary law of Holland. The extent to which the work departs from De jure belli ac pacis differs according to the area of law under discussion, but Grotius himself noted the closeness with which local law and natural paralleled one another when it came to wrongdoing. ${ }^{42}$ There are, however, several notable examples raised by local law that do not fit comfortably within the natural law framework, and Grotius goes to some lengths to cast them in a manner that reduces the friction between the two regimes. ${ }^{43}$

Fault is not a concept confined to obligations arising out of wrongdoing in the Inleidinge. It arises in both delictual and contractual contexts and in each carries the same approach that can be found in the Corpus juris civilis and subsequent commentaries. In the context of liability for wrongdoing, the terminology of fault is largely undefined. The language used indicates two degrees of culpability: willfulness or fault, which map directly onto the Latin dolus (intentional wrongdoing) and culpa used in the context of the lex Aquilia. ${ }^{44}$ Instead of defining these terms, Grotius instead focuses on situations where a person isn't at fault, relying on a series of excuses that render prima facie unlawful conduct lawful. The examples are all strongly reminiscent of central texts on iniuria or unlawfulness under the lex Aquilia: it is not culpable to exercise arms in a place where such practice is customary, or to prune away from a public highway, or to kill a thief caught in the night, or in self-defence. ${ }^{45}$ The traditional iniuria approach with its focus on whether the act can be positively

42 Grotius, Inleidinge, 3.32.7. On the dynamic between local law and natural law generally, see 1.2.5.

43 For a fuller account of the differences between Grotius's two approaches to delict, see Sampson, 'The Limits of Natural Law', 7-27.

44 E.g. in Grotius, Inleidinge, 3.37.2.

45 Martial practice: Grotius, Inleidinge, 3.33.7, Dig. 9.2.9.4 (though a distinction can be drawn between this text, where exculpation is provided by the act of practising throwing javelins, and Inst. 4.3.4, where it is the geography of the location, and the fact the space is regularly used as a training ground, which furnishes the exculpation). See further Helen Scott, 'Pits and Pruners: Culpa and Social Practice in Digest 9.2', in: Judge and Jurist: Essays in Memory of Lord Rodger of Earslferry, ed. by Andrew Burrows, David Johnston, and Reinhard Zimmermann (Oxford: Oxford University Press 2013). In this respect, Grotius's example is closer to Inst. 4.3.4 than Dig. 9.2.9.4; pruning: Dig. 9.2.31, Inst. 4.3.5; thieves: Dig. 9.2.4.1, Inst. 4.3.2; self-defence: $\operatorname{Dig} \cdot 9 \cdot 2.5$. 
justified (or else be branded non iure) characterises Grotius's approach. The only hint of Grotius's natural law influences comes in his discussion of the ways in which parties other than the primary wrongdoer might be causally salient, which is strongly reminiscent of the treatment of the same subject in De jure belli ac pacis. ${ }^{46}$ Just as his discussion of fault in the realm of delict is representative of civilian orthodoxy, so too is Grotius's analysis of contractual fault, which is primarily found in texts on real contracts and raises the familiar variations of culpa based on the level of care expected of reasonable people, and the level of care typically taken by the defendant in his own affairs. ${ }^{47}$

Within Grotius's taxonomy of the law of Holland, liability for wrongdoing arises - as in natural law - as a species of inequality-generated norms. Obligations are universally generated by the creation of inequality, an idea that is subject to two further subdivisions: firstly, between inequalities caused by withholding profits so as to make a gain of, and inequalities caused by another; secondly, inequalities caused by another being divided into those brought about through amical or inimical events. ${ }^{48}$ It is the last of these manifold subdivisions that entails liability for wrongdoing. Thus far, as explored above, Grotius's structure in the Inleidinge closely tracks that found in De jure belli ac pacis, albeit with a subtly different focus on factual events (i.e., extant inequalities) rather than the idea of debt. However, a further subdivision of obligations generated by inimical events takes Grotius into terra incognita: such obligations can be divided into those that arise ex maleficio or ex quasi maleficio. ${ }^{49}$

The idea of an obligation ex quasi maleficio is not something that exists within the natural law framework, although several obligations that are discussed under this heading in the Inleidinge are also mentioned in De jure belli ac pacis, albeit with a view to explain why they do not belong in natural law. ${ }^{50}$ In that work, Grotius is inconsistent within the space of a single text in explaining why they are not obligations ex maleficio, arguing in consecutive sentences that it is down to either the absence of fault on the part of the dominus, or the difficulty of proving fault. ${ }^{51}$ It is possible that different rationales explain the classification of different obligations as ex quasi maleficio, but Grotius appears to be presenting a unitary rationale rather than specific reasons tailored to each obligation.

The same uncertainty characterises Grotius's discussion of obligations ex quasi maleficio in the Inleidinge. In his introduction to the topic, he claims that

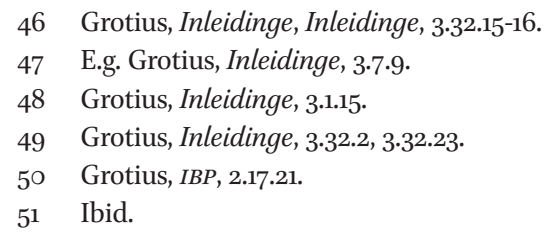


these obligations cannot be called truly delictual because of the difficulties of proving fault. ${ }^{52}$ They are still obligations predicated on fault, but with the need to prove said fault elided due to evidential difficulties. This is avowedly not a species of strict liability obligation (sensu stricto.) As such, it is presumably the case - though it is not expressly stated by Grotius - that the ability to prove the absence of fault would exculpate a defendant. Such a category of obligation is said not to arise in natural law because in such a domain, we look to the truth of the act' - difficulties in substantiating a claim through evidence do not arise, and so in that context, there is no need for anything other than liability founded on fault: ex maleficio. ${ }^{53}$

This is not consonant with the definition of obligations ex quasi maleficio given at the outset of the topic's dedicated treatment. Here Grotius writes that these obligations can arise when the law imputes a delict, even if there is no wrongdoing. ${ }^{54}$ The category is at least partially recast as a species of obligation that arises due to harm being caused without lawful grounds. This takes Grotius into territory entirely unlike that covered by maleficium in De Jure Belli ac Pacis. Rather than being putatively fault-based, the category is now being presented as a miscellany of obligations residually grouped together due to the absence of any better means of explaining how they fit into the taxonomy of private law.

The reason for the shift in explanation is made clear when examining the substance of the category. There are multiple obligations that are difficult to characterise other than as instances of strict liability. Perhaps the starkest example is a narrow instance of liability: "[a] waggoner or countryman whose horses run away is bound to make compensation, even were it without his fault. 55 In his commentary on the treatise, Groenewegen tries to recast the obligation into one founded on fault through a comparison with Dig.9.2.8.1. This text, about the liability under the lex Aquilia of a muleteer who loses control of his animal so as to cause loss, concerns the possibility of showing fault (culpa) through a lack of skilfulness (imperitia). Without such fault, there could be no liability under the lex Aquilia. The ultimate explanation - that it is justifiable to use imperitia to establish culpa - runs directly against the explanation given by Grotius that this obligation arises even in the absence of individual fault. Rather, Groenewegen's efforts to reanalyse the scenario show

$5^{2}$ Grotius, Inleidinge, 3·32.22.

53 Ibid.

54 Grotius, Inleidinge, 3.38.1.

55 Grotius, Inleidinge, 3·38.12. The key phrase 'even without his fault' (alwaer't buiten sijn schuld) is unambiguous. 
how anomalous this liability is within the Grotian framework and the implicit necessity of fault for delictual liability.

Liability for the acts of others furnishes further examples. Typically, masters are only liable for wrongs committed by those in their employee to the extent of any unpaid wages. ${ }^{56}$ No reference is made to fault, though the cap on damages at the sum owed to the wrongdoer (in a manner that mirrors claims against the peculium in Roman law, as recognised by Groenewegen) suggests this is a form of liability that facilitates recovery by the wronged party rather than redressing the wrongdoing of the defendant. This reinforces the sense that Grotius is using obligations ex quasi maleficio to group together heads of liability that defy any classification other than residuality. However, liability for innkeepers, stable-keepers, and ship captains takes matters further, making the defendant professionals responsible for all damage sustained by the claimant, whether to life or property, by an employee within the place of employment. ${ }^{57}$ No reference is made to fault, even though Justinian's Institutes provides a convenient means of explaining how such an obligation can be predicated on fault in choosing one's employees poorly. ${ }^{58}$ Instead, the obligation appears to be absolute.

Other obligations within the category seem more indicative of the "presumptive fault" rationale provided in De jure belli ac pacis and earlier in the Inleidinge. The standout example is the rule laid down in a placaat of $1551 .{ }^{59}$ This provides that where two ships collide so that one suffers damage, including destruction, the loss is borne equally by the two parties. ${ }^{60}$ However, if it can be proven that one of the two was at fault, then that party is liable to the full sum. A similar rule applies for ships at anchor: where a ship collides with another at anchor, the loss is split equally between the two parties, unless the party at anchor can prove the incident was solely the fault of the ship at sail. ${ }^{61}$ Both these scenarios appear to presume that both parties are to blame for the incident, with the possibility of exculpation by proving to the satisfaction of the court that it was actually caused by the fault of just one party.

There is a miscellany of obligations between these two positions that are not explained by either rationale, though each is plausible. The escape of fire

56 Grotius, Inleidinge, 3.38.8.

57 Grotius, Inleidinge, 3.38.9. The parallels with the Roman obligations quasi ex delicto for shippers, innkeepers and stable-keepers is unmissable.

$58 \quad$ Inst. 4.5.3.

59 P. Van Waesberge, Keuren ende privilegien des Lands ende Heerlijckheyts van Voorne (Rotterdam, 1717), p. 113 (Article CXVIII); see Sampson, 'The Limits of Natural Law', p. 9.

6o Grotius, Inleidinge, 3.38.16.

61 Grotius, Inleidinge, 3.38.17. 
from the defendant's land onto that of another is - somewhat surprisingly dealt with as an obligation ex quasi maleficio. ${ }^{62}$ Causing property damage by fire is expressly identified as one form of the most serious species of wrong to a property where caused wilfully or negligently. ${ }^{63}$ As such, this text must be dealing with situations where fire escapes other than wilfully or negligently. This could either mean that the fire escaped under circumstances where the defendant is less than negligent - supporting a strict liability analysis - or where it is impossible to prove the required fault element, thereby supporting a presumptive fault analysis. Grotius does not provide more information, though the obligation is discussed in a text that immediately follows his definition of ex quasi maleficio as dealing with loss caused without maleficium, perhaps supporting a strict liability reading. The same ambiguity colours his treatment of archetypically Roman obligations quasi ex delicto, such as the liability of occupiers for things thrown out of the premises onto a public highway so as to cause injury. ${ }^{64}$

\section{The Place of Fault in Grotius's Conception of Liability for Wrongdoing}

Simply put, fault sat at the heart of Grotius's accounts of wrongdoing in both natural and local law. The absence of fault signalled that the obligation in question was something anomalous or other. Given the extent to which Grotius drew upon early doctrinal traditions that themselves were wedded to the centrality of fault, this is as one would expect. The incorporation of civilian learning into Thomist doctrine on matters of culpability meant that Grotius's source material presented a united front, both in terms of the role of fault and its specific manifestations. It is consequently noteworthy that Grotius does not offer quite the same approach to fault as that found in the likes of Lessius. Rather than offering specific degrees of culpability, Grotius uses a self-understood, fluid notion of fault that is most reminiscent of the ancient jurists' commentaries on the lex Aquilia. It does not, however, detract from the lynchpin function fault plays within liability for wrongdoing. Without fault, the obligation would need to be cast in a completely different light.

62 Grotius, Inleidinge, 3.38.2.

63 Grotius, Inleidinge, 3.37.2.

64 Grotius, Inleidinge, 3·37.3-4. Grotius also deals with hanging/suspending in broadly Romanist terms: Inleidinge, 3.37.5; the key difference is that Grotius imposes liability only where harm is actually caused, whereas the Roman obligation would arise from the act of hanging alone (giving rise to a popular action). 